\title{
The Effectiveness of Communication from the National Disaster Management Agency's Twitter Account on Public Adherence to the Covid-19 Health Protocol
}

\author{
Laura Berlian Surya Puteri ${ }^{1}$ Farid Rusdi ${ }^{1 *}$ \\ ${ }^{1}$ Faculty of Communication, Universitas Tarumanagara, Jakarta 11440, Indonesia \\ *Corresponding author. Email: farid@fikom.untar.ac.id
}

\begin{abstract}
Covid-19, which emerged in early December 2019, made the pattern of society change in communication because it was required to comply with health protocols, one of which was by maintaining distance between individuals. The regulation makes face-to-face meetings decreases; it causes social media use to increase. Many organizations create social media platforms to raising awareness through social media. Various kinds of social media are used, such as Facebook, Instagram or Twitter. From the various existing social media, this research wants to know how effective social media twitter for public obedience in following the health protocol (@BNPB_Indonesia Twitter followers). This research was conducted with quantitative research methods using the Slovin formula. The author takes 100 respondents from a total of 364,200 who have followed the @BNPB_indonesia account. The coefficient shows that there is a strong relationship between communication variables and adherence variables. The communication effectiveness variable influenced public adherence to $46 \%$ while the remaining $54 \%$ can be influenced by other factors. The more an institution pays attention to strategies to increase the effectiveness of its communication, the more public adherence could be increased.
\end{abstract}

Keywords: Communication effectiveness, obedience, twitter, Covid-19

\section{INTRODUCTION}

Humans cannot be separated from communications. This is proven through research which shows that the percentage of humans is communicating around $75 \%$ to $90 \%$ of the time of activity [1]. Humans had various ways to communicate, therefore communication is always present in our daily life. Furthermore, what is meant by communicating is a form of delivering messages from one source to the others with a certain channel. Someone who convey the messages called communicator, then someone who received the messages can be called audience or communicant, and a communication channel can be called as a channel and this can have certain effects. In this 21 Century, humans and technology also mingled in a complex way creating a dependency on technology. The internet, as a form of technology, gives rise to new media. Communication becomes unlimited in space and time, so that an unlimited flow of information appears [2].

In Indonesia, internet users reach 171,17 million of the total population Indonesia which reached 264,16 million people, with the highest reason for using the internet in daily life is using social media, amounted to $52,2 \%$ and followed with communication via message which amounted to $32,9 \%$ [3]. Looking at the survey results, it can be seen that most internet users are used to surfing social media. This shows the possibility that information disseminated through social media will have a major impact on the everyday life of its users.

Some popular social medias in Indonesia are Youtube, Facebook, Instagram, and Twitter. From list of most used social media in Indonesia released by "We are Social", Twitter ranks 5th which reaches 56\% users in Indonesia (katadata 2020). According to the financial reports published in 2019, Twitter users who are daily active have increased $17 \%$, with Indonesia being claimed to be the country with the largest growth in Twitter users. Social media is useful to interact in a virtual world that blurs the line distance and time. According to Effendy [4], the increase of communication technology has an effect on the effectiveness of media communication. Current media communication is also supported by devices that connected to the internet, such as mobile phones, laptops, or tablets. The National Disaster Management Agency of the Republic of Indonesia (BNPB RI) is using Twitter, as one of the most used social media in Indonesia, to disseminate information related to various disasters that is currently happening in Indonesia, one of the case is the Covid-19 Pandemic that has been detected in March 2020. 
The head of the National Disaster Management Agency of the Republic of Indonesia (BNPB RI) was appointed by the president as the task to to preventing Covid-19 and provide direction to all regions. The National Disaster Management Agency has the task of providing guidelines and direction for disaster management, establishing standardization and disaster management needs based on statutory regulations. BNPB RI in urging to comply with health protocols, often uses social media to campaign health protocols in preventing Covid-19 disease. One of the social media that used by National Disaster Management Agency is Twitter with account named @BNPB_Indonesia. BNPB RI often urges the public to social distancing, wear masks, and wash their hands with soap or hand sanitizer to prevent the Covid-19 transmission.

Based on the above background, the author wants to find out how much BNPB RI on Twitter is effective in urging the public to obedience with health protocol to prevent Covid-19 in Indonesia.

\subsection{Related Work}

According to the generation type of assumptions, we divided the existed work into two categories.

\subsubsection{The Use of WhatsApp as a Communication Media on the Effectiveness of Employee Performance}

Conducted by Andjani, Ratnamulyani, and Kusumadinata, in 2018. This research aims to determine the efectiveness of WhatsApp as one of the most used communication media and its effect towards employee performance. The research uses the 'Social Media' theory by Rohmadi, describes that social media is a media that allows its users to socialize and interact with various information, as well as the collaboration between its users. In addition to the theory, the research also uses the Theory of Effectiveness by Effendy (2004) which defines effectiveness as a communication process that is expected to achieve results according to the plan with budgeted costs, predetermined time, and the number of people who have been determined. This research uses explanative quantitative research methods (analytic) by collecting data through questionnaires and data analysis. The results of this study are the use of WhatsApp communication media at XX company. The result of this study is to prove of the correlation between WhatsApp usage and the employee performance; there is a strong correlation between social media and employee performance.

\subsubsection{The Influence of Whatsapp Social Media: Its Effectiveness towards Employee Communication}

The second one is a research conducted by Pepen Sumirat entitled, "The Influence of Whatsapp Social Media: Its Effectiveness towards Employee Communication at PT Asia
Dwimita Industri, Tangerang" in 2017. This study discusses the effect of the use of WhatsApp on interpersonal communication at PT Asia Dwimitra Industri. This research uses an idea by Joseph A. Devito who explained that explained the communication patterns, which contains of interpersonal communication, small group communication, mass communication and public communication. As well as 'New media' or 'Online media' is defined as a product of technology-mediated communication that is shared with digital computers (Creeber and Martin, 2009). The purpose of this study was to determine the effect of using the WhatsApp application on interpersonal communication. Furthermore, the method used is quantitative descriptive for the study aims to describe an event that occurred. The population of this study were 92 and have been calculated using the Yamane formula. The analysis showed that there were significant result of WhatsApp messenger usage to personal communication with the calculation of $t$-Test to the hypothesis, and the obtained tCalculate is bigger than tTable $(2.876>1.990)$ with a significant level of $5 \%$. While the $5 \%$ significance level used in the Hypothesis Test is obtained by a number of 0.05 , so $\mathrm{H} 1$ is accepted, meaning there is an influence of WhatsApp messenger usage on the employee's interpersonal communication. The amount of influence is $0.84 \%$, when the rest is influenced by other factors outside the research.

\subsubsection{The Influence of Social Media Use of the Instagram Account on Fulfilling Followers Information Needs}

The last one is a study titled, " The Influence of Social Media Use of the @jktinfo Instagram Account on Fulfilling Followers Information Needs " in 2018. This study aims to determine the effect of using the @ jktinfo Instagram account on fulfilling information needs for the followers. The theories used in this research include the Mass Communication theory, the New Media theory, the Uses and Gratification theory, and the Use of Social Media and the Needed of Information Needs theory. The research method used in this research is by distributing questionnaires to 100 respondents who are determined by non-probability sampling and incidental sampling techniques. The data obtained is the use of Instagram has a significant effect on fulfilment of information needs for the @jktinfo Instagram account followers.

\subsection{Our Contribution}

As mentioned above, this study aims to determine whether or not the role of @BNPB_Indonesia Twitter account is has been successful to increase the level of public obedience with health protocols, in particular for people who are followers of the account. The benefit of this research, conducted by the author, are it is hoped that this research will be useful for the development of Communication science, as well as a reference for further research, particularly in correlation between the National Disaster Management Agency of the Republic of Indonesia (BNPB 
RI) Twitter account and public obedience with health protocols.

\subsection{Paper Structure}

The rest of the paper is organized as follows. Chapter 1 is introduces the communication and humans in everyday life. Chapter 2 presents a theory of communication effectiveness, new media, and obedience. In Chapter 3 and 4 is explaining which method this research used and telling the results with table and explained and Finally, Chapter 5 concludes the paper and presents direction for future research.

\subsection{Research Hypothesis}

$\mathrm{H}_{0}$ : There is no effect of communication effectiveness of Twitter social media as a media conveying Covid-19 information towards the public obedience through the @BNPB_Indonesia Twitter account followers.

$\mathrm{H}_{1}$ : There are some effects of communication effectiveness of Twitter social media as a media conveying Covid-19 information towards the public obedient through the @BNPB_Indonesia Twitter account followers.

\section{BACKGROUND}

\subsection{Communication Effectiveness}

The effectiveness of communication can also be referred as a communication strategy, that is combination between planning and a management that good for achieving a purpose [4] These goals can be divided into three main objectives, that is for giving information, to give comprehension, and to take an action. Communication is the delivery of messages, thought, idea as well as the feeling of the communicator to the communicant or other people.

From the description, there is four important factor that need to pay attention when develop a communication strategy:

1. Define Audience

Before doing good communication strategy, the communicator must determine who the target audience of the communication. Is the goal just to get information, or get information at the same time to take an action?

2. Determining the Media of Communication

To achieve communication goals, the communication media used must be appropriate. It all depends on the goals to be achieved, the message to be given, and the techniques to be used.

3. Determining Message Purpose Communication Message have some purpose. That goal usually determines the communication techniques used, whether using information techniques, persuasion techniques or instructional techniques. Although the techniques used are varied, the communicant or the recipient of the message must understand the message being conyeyed. Message content can be only one, but can use various symbols.
4. The Role of the Communicator on Communication The important factors found in communicators when unleash communication are source attractiveness and source credibility.

\subsection{New Media}

In production delivery of a messages, new media is a medium that offers digitalization, convergence, interactivity and network development. The interactivity offered by new media users is the ability to sort the information to be used as well as output information, and make some choices. This interactivity is the central concept of understanding new media [5]. According to Denis McQuail in the book of Mass Communication Theory, the main characteristic of new media are their interconnectedness, their access to individual audience can be both the recipient and the sender of the message, and their interactivity. The new media allows for conversational between multiple parties, allows simultaneous acceptance, change and re-propagation of cultural objects, disrupts communications of its importance, regional relations and modernity, and also provides instant global contact [6]

\subsection{Obedience}

Obedience theory introduced by Milgram. [7] states that individuals tend to obey because of the authority. The factors that influence the Milgram's experiment are as:

1. Location Status

2. Personal Responsibilities

3. Legitimacy of Authority Figures

4. Figure Status Authority

5. Peer Support

6. The Closeness of the Authority Figure

\section{METHODS}

\subsection{Research Method}

This research, we use the quantitative method, that can be interpreted as a research method based on the philosophy of positivism, used to research a particular population or sample, which this sampling technique is generally carried out randomly [8]. The approach to this research uses a quantitative approach. This approach considers that human behaviour is can be predictable and cross-social, objective and measurable [9].Quantitative research is still considered a valid and reliable instrument and appropriate statistical analysis that can cause research result not to deviate from the actual conditions. In this study, the researcher wanted to find out whether the use of social media was effective for public to obeyed to health protocol to prevent Covid-19. 


\subsection{Population and Sample}

According to Sugiyono, the definition population is, a generalization area consisting of objects and subjects that have certain qualities and characteristics that are determined by the researcher to be studied and make a conclusion.

This research population were all followers of the official Twitter account @BNPB_Indonesia, from the sum of 36,500 , the sample measurement is a step to determine the size of the sample taken in carrying out. To determine the size of the sample is can be done in such a way.

Following the Slovin Formula and calculations below, researcher get 100 sample in total.

$$
\begin{aligned}
& \mathrm{n}=\frac{364.200}{\left(364.200 \cdot 0.1^{2}\right)+1} \\
& \mathrm{n} \quad=99.97 \\
& \mathrm{n} \quad=100
\end{aligned}
$$

\subsection{Data Collection Method}

This research uses several data techniques including through several ways such as questionnaires and documentation. Questionnaire is a research instrument that contain question or statement that must be answered by respondents [10]. Researchers use closed question because the data that obtained will be easier to process. Documentation is a technique that the authors use in capturing records of past events. These notes are usually photos, audio or an article. The documentation is in the form of text books and secondary data on the internet as research data.

\subsection{Validity and Reliability}

According to Sugiyono, validity is the degree between data that actually occurs on the object of research and data that can be reported by researchers. Thus, valid data is "data that does not differ" between the data reported by the researcher and the data that actually occurs as the research object. The validity of the data in the study was determined by an accurate measurement process. The research instrument in the form of a questionnaire will be valid if it measures what should be measured so that it is in accordance with what expected by the researcher and can be accounted for. The validity test in this study is using the pearson product moment statistical method, by comparing the question $\mathrm{X}$ variable with the total variable $\mathrm{Y}$ and the variable $\mathrm{Y}$ question with the total $\mathrm{X}$ so that the following conclusions are obtained : Valid : $r$ count $>r$ table, Invalid $: r$ count $<r$ table. Reliability test used to determine the consistency of measuring instruments used using a questionnaire. The method commonly used for range scales is Cronbach Alpha. The Reliability test is a continuation of the validity test, the items entered are only valid items. This test is a continuation of the validity test [11]

\subsection{Coefficient of Determination}

Data management is performed using the IBM SPSS Statistic software application tool so that the measurement of the resulting data is more accurate.

\subsection{Correlation}

According to Sunyoto [12], correlation analysis is to test whether two variables, namely the independent variable and the dependent variable, have a strong or insufficient relationship, whether the relationship is positive or negative. To determine the strength or weakness of the relationship between the independent variable and the dependent variable, the correlation coefficient can be calculated.

\subsection{Simple Regression Test}

According to Sugiyono (2015), simple regression is based on the functional or causal relationship of one independent variable $(\mathrm{X})$ with one dependent variable $(\mathrm{Y})$. Simple linear regression analysis is used to test the nature of the causeand-effect relationship between the independent variable (X)

\begin{tabular}{|c|c|c|c|}
\hline Concept & Variable & Indicator & Measurement Scale \\
\hline \multirow[t]{4}{*}{$\begin{array}{l}\text { Communication } \\
\text { Effectiveness }\end{array}$} & $\begin{array}{l}\text { The effectiveness of social } \\
\text { media twitter (Variable X) }\end{array}$ & Defining audience & Likert \\
\hline & & Determine the communication medium & Likert \\
\hline & & Specifies the purpose of messages & Likert \\
\hline & & $\begin{array}{l}\text { The role of communicator of } \\
\text { communication }\end{array}$ & Likert \\
\hline \multirow[t]{5}{*}{ Obedience } & Obedience (Variable Y) & Location Status & Likert \\
\hline & & Personal responsibility & Likert \\
\hline & & Authority figure status & Likert \\
\hline & & Peer support & Likert \\
\hline & & Closeness of authority figures & Likert \\
\hline
\end{tabular}
and the dependent variable (Y).

Table 1 Operationalization of Variables 


\section{FINDINGS AND DISCUSSIONS}

From the questionnaires that have been distributed a sample of 100 people was obtain, with a range of ages 16 to 30 years is 83 respondents, while respondents aged 31 57 years old is 25 respondents. Researchers tested the validity of written statements in the questionnaire. The results of the validity test were declared valid because all count were larger of t table (5\%) and can continue to the next test, namely the reliability test for knowing the consistency of measuring instruments on the same symptom scale.

Table 2 Reliability Test Results

\begin{tabular}{|c|c|c|}
\hline \multicolumn{3}{|c|}{ Reliability Statistics } \\
\hline Cronbach's Alpha & $\begin{array}{c}\text { Cronbach's Alpha Based } \\
\text { on Standardized Items }\end{array}$ & N of Items \\
\hline $\mathbf{3}$ & 0.884 & 10 \\
\hline \multicolumn{3}{|c|}{ Reliability Statistics } \\
\hline Cronbach's Alpha & $\begin{array}{c}\text { Cronbach's Alpha Based } \\
\text { on Standardized Items }\end{array}$ & N of Items \\
\hline 0.858 & 0.869 & 7 \\
\hline
\end{tabular}

The coefficient of determination aims to measure the model in explaining the variation in the dependent variable with a value between zero and one. From the table below, the value of Adjusted $\mathrm{R}$ Square (Coefficient determination) is 0.460 , which means that the variable of communication effectiveness affects the obedience variable by $46 \%$ while the remaining $54 \%$ is influenced by other factors.

Table 3 Coefficient of Determination

\begin{tabular}{|c|c|c|c|c|}
\hline Model & $\mathrm{R}$ & R Square & $\begin{array}{l}\text { Adjusted R } \\
\text { Square }\end{array}$ & $\begin{array}{l}\text { Std. Error } \\
\text { of Estimate }\end{array}$ \\
\hline & .682 & .465 & .460 & 4.469 \\
\hline
\end{tabular}

The analysis obtains through SPSS version 25 shows that the significance value of the table is 0.00 . Based on decision making are:

If the significance value $<0.05$ then it is correlated.

If the significance value $>0.05$ then there is no correlation.

Table 4 Correlation

\begin{tabular}{|l|l|l|l|}
\hline \multicolumn{2}{|c|}{} & $\begin{array}{l}\text { Communication } \\
\text { Effectiveness }\end{array}$ & Obedience \\
\hline $\begin{array}{l}\text { Communication } \\
\text { effectiveness }\end{array}$ & $\begin{array}{l}\text { Pearson } \\
\text { Correlation }\end{array}$ & 1 & .682 \\
\cline { 2 - 4 } & $\begin{array}{l}\text { Sig. (2- } \\
\text { tailed) }\end{array}$ & & .000 \\
\cline { 2 - 4 } & $\mathrm{N}$ & 100 & 100 \\
\hline Obedience & $\begin{array}{l}\text { Pearson } \\
\text { correlation }\end{array}$ & $.682^{* *}$ & 1 \\
\cline { 2 - 4 } & $\begin{array}{l}\text { Sig. (2- } \\
\text { tailed) }\end{array}$ & .000 & 100 \\
\cline { 2 - 4 } & $\mathrm{N}$ & 100 & \\
\hline
\end{tabular}

From the table 4 below, it can be seen that the variables of communication effectiveness and compliance are correlated. From the calculation results in table, it is known that the correlation coefficient value is 0.683 , and the closeness of the relationship or correlation coefficient between variables that is between the interval from 0.41 0.70 means a strong relationship [13].

Table 5 Simple Regression

\begin{tabular}{|c|l|l|l|}
\hline Model & & $\begin{array}{l}\text { Unstandardized } \\
\text { B }\end{array}$ & $\begin{array}{l}\text { Coefficients } \\
\text { Std. Error }\end{array}$ \\
\hline 1 & (Constant) & 8.732 & 2.403 \\
\hline & $\begin{array}{l}\text { Communication } \\
\text { Effectivity }\end{array}$ & 1.029 & .111 \\
\hline
\end{tabular}

\begin{tabular}{|c|c|c|}
\hline $\begin{array}{l}\text { Standardized } \\
\text { Coefficients (Beta) }\end{array}$ & $\mathrm{t}$ & Sig. \\
\hline & 3.634 & .000 \\
\hline .682 & 9.236 & .000 \\
\hline
\end{tabular}

Based on simple linear regression above, it can be described as follows:

1. A constant of 8.732 means that the consistent value of the participation variable is 8,732

2. The regression coefficient of 1.049 states that every $1 \%$ addition of the communication effectiveness value, the participation increases by 1.049 . the regression coefficient is positive, so it can be said that the direction of the influence of the variable $\mathrm{X}$ on $\mathrm{Y}$ is positive.

\section{CONCLUSIONS}

Based on the result, the effectiveness of communication $(\mathrm{X})$ on obedience $(\mathrm{Y}), \mathrm{H} 0$ is rejected and $\mathrm{Ha}$ is accepted. Means that there is an effect of communication effectiveness on obedience by $46 \%$, while the $54 \%$ is another factor that affect obedience. The effectiveness of communication has a strong relationship, towards public obedience with covid-19 health protocols. Thus, the more an institution pays attention to strategies to increase the effectiveness of its communication, the more public obedience will be conversely. If the communication is not effective, then public obedience to covid-19 health protocol will also decrease.

\section{ACKNOWLEDGMENT}

This work was supported by Tarumanagara University, major communications.

\section{REFERENCES}

[1] T. Suprapto, Pengantar Teori \& Manajemen Komunikasi. 2009.

[2] M. Lister, J. Dovey, S. Giddings, I. Grant, and K. Kelly, "New Media: a Critical Introduction, Second Edition."

[3] APJII, "Laporan Survei Internet APJII 2019 - 
2020," Asosiasi Penyelenggara Jasa Internet Indonesia, Vol. 2020, pp. 1-146.

[4] O. U. Effendy, Ilmu Komunikasi. 2007.

[5] T. Flew, "New Media: An Introduction," 2005, p. 302.

[6] D. McQuail, Teori Komunikasi Massa Mcquail, Edisi 6 Buku 1. 2011.

[7] Milgram, "Experiment on Obedience to Authority," 1963. [Online]. Available: https://nature.berkeley.edu/ ucce50/ag-labor/7article/article35.htm. [Accessed: 17Oct-2020].

[8] P. D. Sugiyono, "Metode Penelitian Pendidikan Sugiyono 2015 BAGIAN 3.” p. 458, 2015.

[9] A. M. Yusuf, Metode Penelitian Kuantitatif, Kualitatif \& Penelitian Gabungan.

[10] E. Suryadi, D. Darmawan, and A. Mulyadi, "Metode Penelitian Komunikasi dengan Pendekatan Kuantitatif," 2019.

[11] D. Priyatno, "SPSS Panduan Mudah Olah Data bagi Mahasiswa \& Umum,” 2018.

[12] Sunyoto D, Metodologi Penelitian Akuntansi. Bandung: Refika Aditama, 2013.

[13] V. W. Sujarweni, "Metodologi Penelitian Keperawatan," 2014. 